\title{
PENERAPAN MODEL PEMBELAJARAN KOOPERATIF TIPE NUMBER HEAD TOGETHER DENGAN ALAT PERAGA MATERI BANGUN RUANG KUBUS DAN BALOK PADA PESERTA DIDIK SMP DARUL ULUM MUNCAR
}

\author{
Mekar Arum Kusuma ${ }^{1}$

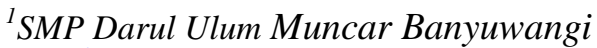 \\ Email: 'mekar.arum.kusuma1996@gmail.com
}

\begin{abstract}
Abstrak
Penelitian tindakan kelas ini dilatar belakangi oleh rendahnya kemampuan peserta didik dalam hal pemahaman konsep dan kemampuan pemecahan masalah. Penelitian ini bertujuan untuk mendeskripsikan penerapan model pembelajaran Number Head Together dengan alat peraga untuk meningkatkan pemahaman konsep dan kemampuan pemecahan masalah pada pokok bahasan bangun ruang kubus dan balok peserta didik kelas VIII-C SMP Darul Ulum tahun pelajaran 2017/2018 yang dilaksanakan pada 16 April 2018 sampai 9 Mei 2018. Jenis penelitian yang digunakan adalah penelitian tindakan kelas dengan 2 siklus, yang terdiri dari 3 pertemuan pada setiap siklus. Adapun tahapan setiap siklus meliputi perencanaan, pelaksanaan, pengamatan dan refleksi. Teknik dan alat pengumpulan data pada penelitian ini menggunakan teknik analisis deskriptif terhadap data berupa dokumen hasil pekerjaan peserta didik, daftar nilai dan hasil observasi. Hasil penelitian menunjukan bahwa dengan model pembelajaran kooperatif tipe NHT dengan alat peraga terjadi suasana pembelajaran yang kondusif sehingga kemampuan pemahaman konsep dan kemampuan pemecahan masalah peserta didik meningkat, dari hasil penelitian, diketahui bahwa siklus I ke siklus II terdapat peningkatan, pada siklus I presentase ketuntasan belajar peserta didik mencapai $66,6 \%$ sedangkan pada siklus II terjadi peningkatan dengan presentase keberhasilan mencapai $86,6 \%$. Disimpulkan bahwa model pembelajaran NHT dapat meningkatkan pemahaman konsep dan kemampuan pemecahan masalah.
\end{abstract}

Kata kunci: penerapan, model pembelajaran kooperatif, Number Head Together, pemahaman konsep dan pemecahan masalah.

\begin{abstract}
This classroom action research was motivated by the low ability of students in terms of understanding concepts and problem solving abilities. The purpose of this study was to describe the application of the Number Head Together learning model with teaching aids to improve concept understanding and problem-solving abilities on the subject matter of building cubes and block of class VIII-C students of Darul Ulum Middle School 2017/2018 academic year held on April 16, 2018 to 9 May 2018. The type of research used was classroom action research with 2 cycles, consisting of 3 meetings in each cycle. The stages of each cycle include planning, implementation, observation and reflection. The data collection techniques and tools in this study used descriptive analysis techniques for data in the form of student work documents, lists of values and observations. The results showed that with the Number Head Together cooperative learning model with teaching aids there was a conducive learning atmosphere so that the ability to understand concepts and students' problem solving abilities increased, from the results of the study, it was known that the first cycle to the second cycle had an increase in the learning cycle. students reached $66.6 \%$ while in the second cycle there was an increase with a percentage of success reaching $86.6 \%$. It was concluded that the NHT learning model could improve concept understanding and problem solving abilities.
\end{abstract}

Key words: implementation, Number Head Together, cooperative learning model, conceptual understanding and problem solving. 


\section{PENDAHULUAN}

Seiring perkembangan zaman, dunia pendidikan juga memerlukan inovasi. Untuk mencapai semua itu, diperlukan paradigma baru guru dalam proses pembelajaran, dari yang semula pembelajaran berpusat pada guru menuju pembelajaran yang inovatif dan berpusat pada peserta didik (Shoimin, 2014:16). Pembelajaran tidak hanya sekedar transfer of knowledge atau menyampaikan pesan kepada peserta didik akan tetapi merupakan aktivitas professional untuk menciptakan pembelajaran kondusif, inspiratif, menantang dan menyenangkan.

Masalah yang sering terjadi pada peserta didik adalah keterbatasan peserta didik dalam mengingat serta memahami apa yang sudah dilihat dan dicatatnya. Kebanyakan peserta didik sering menyalin penjelasan yang mereka terima dari gurunya di buku catatannya, tanpa memperhatikan mana yang perlu dicatat dan mana yang tidak perlu dicatat. Peserta didik juga kurang memahami isi catatan yang peserta didik buat sendiri dengan baik. Hal tersebut terjadi karena banyaknya rumus yang ditulis dan catatan yang dibuat asal dicatat tanpa mengetahui apakah catatan tersebut memiliki keterkaitan yang jelas satu sama lain.

Hal lain yang menjadi masalah kebanyakan peserta didik selain kesulitan mencatat dan memahami adalah mengorganisasikan atau memetakan persoalan serta minat membaca kembali catatannya. Kebanyakan catatan yang telah dicatat peserta didik pada jam pelajaran ditinggalkan begitu saja. Hal itu disebabkan kurang menariknya catatan mereka. Apalagi pelajaran matematika yang tidak lepas dari rumus yang membingungkan, serta pencatatan tanpa pengorganisasian dan pemetaan yang memicu ingatan sehingga mempermudah memahami konsep-konsep yang diberikan oleh guru.

Permasalahan lain yang terjadi dalam pembelajaran yaitu kurangnya kemampuan pemecahan masalah matematika. Depdiknas (dalam Suherman, 2001:56) mengemukakan bahwa salah satu tujuan pembelajaran matematika adalah agar peserta didik memiliki kemampuan memecahkan masalah yang meliputi kemampuan pemahaman masalah, merancang model matematika, menyelesaikan model dan menafsirkan solusi yang diperoleh. Tujuan tersebut menempatkan kemampuan pemecahan masalah menjadi bagian dari kurikulum matematika yang penting. Dalam proses pembelajaran maupun penyelesaian masalah, peserta didik dapat memperoleh pengalaman menggunakan pengetahuan serta keterampilan yang sudah dimiliki. Pengalaman inilah yang kemudian melatih daya pikir peserta didik menjadi logis, analitis, sistematis, kritis, dan kreatif dalam menghadapi persoalan.

Melalui latihan memecahkan masalah, peserta didik akan belajar mengorganisasikan kemampuannya dalam menyusun strategi yang sesuai untuk menyelesaikan masalah. Krulik dan Rudnick (dalam Hendriana, dkk., 2017:44) mengemukakan bahwa kemampuan pemecahan masalah merupakan proses dimana individu menggunakan pengetahuan, keterampilan, dan pemahaman yang telah diperoleh untuk menyelesaikan masalah pada situasi yang belum dikenalnya. Jika seorang peserta didik telah berlatih menyelesaikan masalah, maka dalam kehidupan nyata, peserta didik itu akan mampu mengambil keputusan terhadap suatu masalah, sebab dia mempunyai keterampilan mengumpulkan informasi yang relevan, menganalisis informasi, dan menyadari betapa perlunya meneliti kembali hasil yang telah diperoleh.

Berdasarkan hasil wawancara dengan salah satu pendidik mata pelajaran matematika yaitu Bapak Syaikhul Hadi, S.Pd yang dilakukan di SMP Darul Ulum Muncar Banyuwangi, peneliti tertarik melakukan kegiatan penelitian di kelas VIII-C karena minat peserta didik terhadap pelajaran matematika masih kurang, hal ini dilihat dari rata-rata nilai UTS kelas VIII-C yaitu 59,9 dan belum mencapai KKM yaitu 75, namun antusias dalam belajar di kelas VIII-C tergolong cukup baik. Secara umum, metode yang digunakan oleh pendidik mata pelajaran matematika adalah model konvensional atau ceramah dimana pendidik menerangkan materi, kemudian pendidik memberikan contoh soal dan pendidik juga yang menyelesaikannya, peserta didik hanya menerima saja karena pembelajaran masih didominasi oleh pendidik. Hal ini membuat peserta didik cenderung pasif, bosan dan tidak memperhatikan sehingga pembelajaran dengan model konvensional masih kurang efektif karena peserta didik kurang diberi peran dalam pembelajaran.

Untuk mengatasi permasalahan tersebut, salah satunya dengan menerapkan model pembelajaran kooperatif tipe NHT adalah suatu model pembelajaran berkelompok yang setiap angggota kelompoknya bertanggung jawab atas tugas kelompoknya, sehingga tidak ada pemisahan antara peserta didik yang satu dan peserta didik yang lain dalam satu kelompok untuk saling memberi dan menerima antara satu dengan yang lainnya (Shoimin, 2014:108). Langkah-langkah model pembelajaran kooperatif tipe NHT sebagai berikut: (a) Fase 1: Penomoran (Numbering); (b) Fase 2: Pengajuan Pertanyaan (Questioning); (c) Fase 3: Berpikir Bersama (Heads Together); (d) Fase 4: Pemberian Jawaban (Answering). Dengan tipe ini, peserta didik dapat 
berdiskusi dengan kelompok dan masing-masing peserta didik harus paham tentang materi yang dipelajari karena guru akan menunjuk secara acak untuk mempresentasikan hasil diskusinya di depan kelas. Untuk lebih memudahkan peserta didik dalam mempelajari pemahaman konsep dan kemampuan pemecahan masalah matematika materi bangun ruang kubus dan balok, maka dalam pembelajaran juga diperlukan media pembelajaran untuk dapat mendukung proses pembelajaran di kelas agar lebih optimal. Salah satu media pembelajaran yang dapat digunakan adalah alat peraga. Dengan bantuan alat peraga, pembelajaran akan lebih menarik, menjadi konkret, mudah dipahami, hemat waktu dan tenaga, sehingga pembelajaran lebih bermakna.

Berdasarkan uraian di atas, maka peneliti tertarik untuk melakukan penelitian dengan judul "Penerapan Model Pembelajaran Kooperatif Tipe Number Head Together dengan Alat Peraga untuk meningkatkan Pemahaman Konsep dan Kemampuan Pemecahan Masalah Matematika Peserta Didik Pokok Bahasan Bangun Ruang Kubus dan Balok pada Peserta Didik Kelas VIII-C SMP Darul Ulum Muncar".

Berdasarkan konteks penelitian di atas maka rumusan masalah dalam penelitian ini adalah "Bagaimanakah penerapan model pembelajaran kooperatif tipe NHT dengan alat peraga untuk meningkatkan pemahaman konsep dan kemampuan pemecahan masalah matematika pokok bahasan bangun ruang kubus dan balok pada peserta didik Kelas VIII-C SMP Darul Ulum"?

Sesuai dengan rumusan masalah maka tujuan penelitian ini adalah untuk mendeskripsikan penerapan model pembelajaran kooperatif tipe NHT dengan alat peraga untuk meningkatkan pemahaman konsep dan kemampuan pemecahan masalah matematika pokok bahasan bangun ruang kubus dan balok pada peserta didik kelas VIII-C SMP Darul Ulum.

Alat peraga adalah media alat bantu pembelajaran, dan segala macam benda yang digunakan untuk memperagakan materi pembelajaran. Pemahaman konsep matematika adalah kompetensi dasar dalam belajar Matematika yang meliputi: kemampuan menyerap materi, mengingat rumus dan konsep matematika serta menerapkannya dalam kasus sederhana atau dalam kasus serupa, memperkirakan kebenaran suatu pernyataan, dan menerapkan rumus dan teorema dalam penyelesaian masalah. Indikator yang digunakan untuk meningkatkan pemahaman konsep matematika peserta didik dalam penelitian ini meliputi: a) Menyatakan ulang konsep yang telah dipelajari; b) Mengklarifikasi objek-objek berdasarkan dipenuhi tidaknya persyaratan yang membentuk konsep tersebut; c) Mengidentifikasi sifat-sifat operasi atau konsep; d) Menerapkan konsep secara logis; e) Memberikan contoh atau contoh kontra (lawan contoh) dari konsep yang dipelajari; f) Menyajikan konsep dalam berbagai bentuk representasi matematis (tabel, grafik, diagram, sketsa, model matematika, atau cara lainnya); g) Mengaitkan berbagai konsep dalam Matematika maupun di luar Matematika; h) Mengembangkan syarat perlu dan atau syarat cukup suatu konsep.

Pemecahan masalah matematika adalah proses yang dilakukan seseorang untuk mendapatkan solusi atau kesulitan yang didapatkan seseorang dalam menyelesaikan soal yang tidak biasa diselesaikan secara rutin, sehingga seseorang tersebut harus mendapatkan caranya sendiri. Indikator yang digunakan untuk meningkatkan kemampuan kemampuan pemecahan masalah matematika peserta didik dalam penelitian ini meliputi: (1) memahami masalah; (2) merencanakan pemecahan; (3) melaksanakan rencana; (4) memeriksa kembali.

\section{METODE}

Pendekatan yang digunakan dalam penelitian ini adalah kualitatif, sedangkan jenis penelitiannya adalah penelitian tindakan kelas partisipan. Penelitian ini dilaksanakan di MA Bustanul 'Ulum yang terletak di Jayasakti Anak-Tuha Lampung Tengah. Adapun subjek penelitiannya adalah peserta didik kelas X MIA yang berjumlah 20 peserta didik.

Adapun teknik pengumpulan data dalam penelitian ini dilakukan dengan: (1) wawancara, digunakan untuk mendapatkan informasi lebih mendalam tentang keadaan kelas tersebut yang dilakukan sebelum penelitian, (2) observasi, digunakan untuk mengamati kegiatan guru dan peserta didik selama proses pembelajaran berlangsung, (3) catatan lapangan, digunakan untuk melengkapai data yang tidak tercantum dalam lembar observasi, dan (4) tes, digunakan untuk mengetahui pemahaman konsep dan kemampuan pemecahan masalah.

Instrumen yang digunakan dalam penelitian ini adalah sebagai berikut: (1) pedoman wawancara, (2) lembar observasi, terdiri dari lembar observasi kegiatan guru dan lembar observasi 
kegiatan peserta didik. Observasi dilaksanakan selama proses pembelajaran berlangsung, (3) pedoman catatan lapangan, diisi oleh dua pengamat yaitu guru mata pelajaran matematika kelas VIII-C dan teman sejawat, dan (4) soal tes, menggunakan soal tes tulis dalam bentuk uraian yang disesuaikan dengan indikator kemampuan pemahaman konsep dan kemampuan pemecahan masalah.

Analisis data dilakukan setelah pemberian tindakan. Analisis data dalam penelitian ini terdiri dari: (1) analisis data kualitatif, yaitu: reduksi data (data reduction), penyajian data (data display), dan penarikan kesimpulan atau verifikasi (conclusion drawing/verification), dan (2) analisis data kuantitatif, dianalisis dengan menggunakan rumus persentase ketuntasan belajar dan rata-rata kelas.

\section{HASIL}

Tabel 1. Hasil Observasi Kegiatan Guru Siklus I

\begin{tabular}{|c|c|c|c|c|}
\hline No & Indikator & Skor Maksimal & Skor Pengamat I & Skor Pengamat II \\
\hline \multicolumn{5}{|c|}{ Pertemuan Pertama } \\
\hline 1 & Kegiatan Awal & 20 & 14 & 14 \\
\hline 2 & Kegiatan Inti & 60 & 39 & 40 \\
\hline 3 & Kegiatan Akhir & 15 & 10 & 11 \\
\hline $\begin{array}{l}\text { Tota } \\
\text { Pers } \\
\text { Tar: } \\
\text { Rata }\end{array}$ & $\begin{array}{l}\text { Skor } \\
\text { ntase Skor Rata-Rata (SR) } \\
\text { f Keberhasilan } \\
\text { rata Skor Pengamat } 1 \text { \& } 2\end{array}$ & $\begin{array}{c}95 \\
100 \% \\
\text { Sangat Baik }\end{array}$ & $\begin{array}{c}63 \\
66,31 \% \\
\text { Cukup Baik } \\
67,36 \%\end{array}$ & $\begin{array}{c}65 \\
68,42 \% \\
\text { Cukup Baik }\end{array}$ \\
\hline \multicolumn{5}{|c|}{ Pertemuan Kedua } \\
\hline 1 & Kegiatan Awal & 20 & 15 & 14 \\
\hline 2 & Kegiatan Inti & 60 & 45 & 47 \\
\hline 3 & Kegiatan Akhir & 15 & 12 & 13 \\
\hline $\begin{array}{l}\text { Tota } \\
\text { Pers } \\
\text { Tar: } \\
\text { Rata }\end{array}$ & $\begin{array}{l}\text { Skor } \\
\text { ntase Skor Rata-Rata (SR) } \\
\text { f Keberhasilan } \\
\text {-rata Skor Pengamat } 1 \text { \& } 2\end{array}$ & $\begin{array}{c}95 \\
100 \% \\
\text { Sangat Baik }\end{array}$ & $\begin{array}{c}\mathbf{7 2} \\
\mathbf{7 5 , 7 8 \%} \\
\text { Baik } \\
\mathbf{7 6 , 8 3 \%} \\
\end{array}$ & $\begin{array}{c}74 \\
77,89 \% \\
\text { Baik }\end{array}$ \\
\hline
\end{tabular}

$$
\text { Berdasarkan Tabel 1, diketahui bahwa hasil observasi kegiatan guru pada pertemuan I yaitu }
$$

$=\frac{66,31 \%+68,42 \%}{2}=67,36 \%$ dengan taraf keberhasilan dapat dikategorikan cukup baik. Sedangkan

pertemuan II yaitu $=\frac{75,78 \%+77,89 \%}{2}=76,83 \%$ dengan taraf keberhasilan dapat dikategorikan baik. Sehingga hasil observasi dari dua observer terhadap guru yaitu $=\frac{67,36 \%+76,83 \%}{2}=72,09 \%$ dengan taraf keberhasilan dapat dikategorikan baik.

Tabel 2. Hasil Observasi Kegiatas Peserta didik

\begin{tabular}{|c|c|c|c|c|}
\hline No & Indikator & Skor Maksimal & Skor Pengamat I & Skor Pengamat II \\
\hline \multicolumn{5}{|c|}{ Pertemuan Pertama } \\
\hline 1 & Kegiatan Awal & 20 & 12 & 13 \\
\hline 2 & Kegiatan Inti & 60 & 38 & 40 \\
\hline 3 & Kegiatan Akhir & 15 & 10 & 10 \\
\hline \multirow{4}{*}{\multicolumn{2}{|c|}{$\begin{array}{l}\text { Total Skor } \\
\text { Persentase Skor Rata-Rata (SR) } \\
\text { Taraf Keberhasilan } \\
\text { Rata-rata Skor Pengamat } 1 \& 2\end{array}$}} & 95 & 60 & 63 \\
\hline & & $100 \%$ & $63,15 \%$ & $66,31 \%$ \\
\hline & & Sangat Baik & Cukup Baik & Cukup Baik \\
\hline & & & $64,73 \%$ & \\
\hline \multicolumn{5}{|c|}{ Pertemuan Kedua } \\
\hline 1 & Kegiatan Awal & 20 & 15 & 16 \\
\hline 2 & Kegiatan Inti & 60 & 44 & 46 \\
\hline 3 & Kegiatan Akhir & 15 & 11 & 10 \\
\hline \multicolumn{2}{|c|}{ Total Skor } & 95 & 70 & 72 \\
\hline \multicolumn{2}{|c|}{ Persentase Skor Rata-Rata (SR) } & $100 \%$ & $73,68 \%$ & $75,78 \%$ \\
\hline
\end{tabular}




\section{Taraf Keberhasilan}

Rata-rata Skor Pengamat 1 \& 2

Berdasarkan Tabel 2, diketahui bahwa hasil observasi kegiatan peserta didik pada pertemuan I yaitu $=\frac{63,15 \%+66,31 \%}{2}=64,73 \%$ dengan taraf keberhasilan dapat dikategorikan cukup baik. Sedangkan

pertemuan II yaitu $=\frac{73,68 \%+75,78 \%}{2}=74,73 \%$ dengan taraf keberhasilan dapat dikategorikan baik. Sehingga hasil observasi dari dua observer terhadap kegiatan peserta didik yaitu $=\frac{64,73 \%+74,73 \%}{2}=69,73 \%$ dengan taraf keberhasilan dapat dikategorikan cukup baik.

\section{Hasil Catatan Lapangan siklus I}

Dari hasil catatan lapangan yang dilakukan oleh pengamat I dan II dapat disimpulkan:

1. Respon peserta didik masih kurang, beberapa peserta didik masih tidak memperhatikan.

2. Keadaan kelas masih belum kondusif.

3. Peneliti masih belum bisa mengelola atau mengatur waktu dengan baik.

\section{Tabel 3. Hasil Tes Akhir Siklus I}

\begin{tabular}{lc}
\hline \multicolumn{1}{c}{ Keterangan } & Jumlah \\
\hline Jumlah peserta didik & 30 \\
Jumlah skor seluruh peserta didik & 2250 \\
Rata-rata & 70,46 \\
Nilai tertinggi & 94 \\
Nilai terendah & 50 \\
Peserta didik tuntas & 20 \\
Peserta didik tidak tuntas & 10 \\
Persentase ketuntasan (\%) & $66,6 \%$ \\
\hline
\end{tabular}

Berdasarkan Tabel 3, hasil tes akhir pada pelaksanaan siklus I menunjukkan hanya ada 20 peserta didik yang tuntas dengan persentase ketuntasan belajar peserta didik adalah $66,6 \%$ dan nilai rata-rata kelas adalah 70,46. Rata-rata kelas sudah mencapai kriteria yang ditargetkan oleh peneliti yaitu $\geq 75$. Persentase peserta didik yang tuntas masih kurang dari yang ditargetkan peneliti yaitu $\geq 75 \%$ peserta didik mencapai skor tes $\geq 75$.

Tabel 4. Hasil Observasi Kegiatan Guru Siklus II

\begin{tabular}{|c|c|c|c|c|}
\hline No & Indikator & Skor Maksimal & Skor Pengamat I & Skor Pengamat II \\
\hline \multicolumn{5}{|c|}{ Pertemuan Pertama } \\
\hline 1 & Kegiatan Awal & 20 & 15 & 16 \\
\hline 2 & Kegiatan Inti & 60 & 51 & 52 \\
\hline 3 & Kegiatan Akhir & 15 & 13 & 13 \\
\hline \multicolumn{2}{|c|}{ Total Skor } & 95 & 79 & 81 \\
\hline \multicolumn{2}{|c|}{ Persentase Skor Rata-Rata (SR) } & $100 \%$ & $83,15 \%$ & $85,26 \%$ \\
\hline \multicolumn{2}{|c|}{ Taraf Keberhasilan } & Sangat Baik & Baik & Baik \\
\hline \multicolumn{2}{|c|}{ Rata-rata Skor Pengamat $1 \& 2$} & & $84,20 \%$ & \\
\hline \multicolumn{5}{|c|}{ Pertemuan Kedua } \\
\hline 1 & Kegiatan Awal & 20 & 18 & 19 \\
\hline 2 & Kegiatan Inti & 60 & 54 & 54 \\
\hline 3 & Kegiatan Akhir & 15 & 14 & 14 \\
\hline \multirow{4}{*}{\multicolumn{2}{|c|}{$\begin{array}{l}\text { Total Skor } \\
\text { Persentase Skor Rata-Rata (SR) } \\
\text { Taraf Keberhasilan } \\
\text { Rata-rata Skor Pengamat } 1 \text { \& } 2\end{array}$}} & 95 & 86 & 87 \\
\hline & & $100 \%$ & $90,52 \%$ & $91,57 \%$ \\
\hline & & Sangat Baik & Sangat Baik & Sangat Baik \\
\hline & & & $91,04 \%$ & \\
\hline
\end{tabular}

Berdasarkan Tabel 4, diketahui bahwa hasil observasi pengelolaan pembelajaran guru pada pertemuan I yaitu $=\frac{83,15 \%+85,26 \%}{2}=84,20 \%$ dengan taraf keberhasilan dapat dikategorikan sangat baik. 
Sedangkan pertemuan II yaitu $=\frac{90,52 \%+91,57 \%}{2}=91,04 \%$ dengan taraf keberhasilan dapat dikategorikan sangat baik. Sehingga hasil observasi dari dua observer terhadap guru yaitu $=\frac{84,209,+91,04 \%}{2}=87,62, \%$ dengan taraf keberhasilan dapat dikategorikan sangat baik.

Tabel 5. Hasil Observasi Kegiatan Peserta didik Siklus II

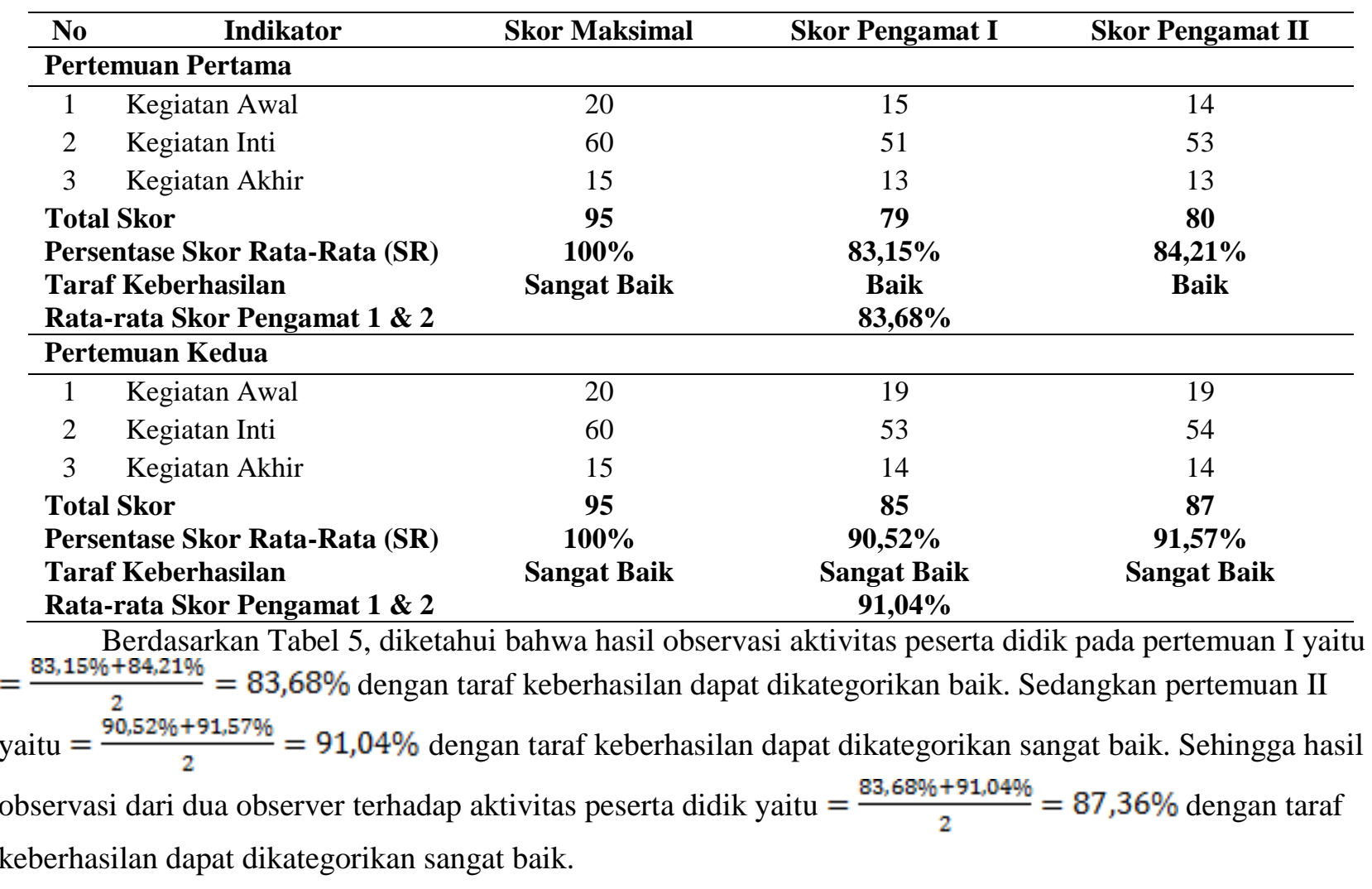

\section{Hasil Catatan Lapangan siklus II}

Dari hasil catatan lapangan yang dilakukan oleh pengamat I dan II dapat disimpulkan:

1. Kegiatan pembelajaran berjalan dengan baik, secara keseluruhan peserta didik sudah terlihat aktif dalam kegiatan berkelompok dan terkondisi.

2. Keadaan kelas cukup kondusif.

Tabel 6. Hasil Tes Akhir Siklus II

\begin{tabular}{lc}
\hline \multicolumn{1}{c}{ Keterangan } & Jumlah \\
\hline Jumlah peserta didik & 30 \\
Jumlah skor seluruh peserta didik & 2450 \\
Rata-rata & 81,66 \\
Nilai tertinggi & 96 \\
Nilai terendah & 62 \\
Peserta didik tuntas & 26 \\
Peserta didik tidak tuntas & 4 \\
Persentase ketuntasan $(\%)$ & $86,6 \%$ \\
\hline
\end{tabular}

Berdasarkan tabel 6 dapat diketahui bahwa keempat aspek yang dinilai dalam penelitian ini seluruhnya telah mencapai kriteria keberhasilan minimal yang ditetapkan, yaitu keterlaksanaan metode pembelajaran NHT dengan alat peraga kegiatan guru dengan persentase $87,62 \%$, kegiatan peserta didik dengan persentase $87,62 \%$, hasil tes akhir siklus mencapai $86,6 \%$, dan respon peserta didik dengan persentase $83,33 \%$. Hasil tersebut mengalami peningkatan dibandingkan hasil yang diperoleh pada siklus sebelumnya. Hal ini berarti bahwa pemahaman konsep dan pemecahan 
matematika peserta didik telah meningkat.sehingga peneliti tidak perlu memberikan tindakan pada siklus berukutnya.

\section{PEMBAHASAN}

Pada pelaksanaan tindakan siklus I dan siklus II, guru memberikan materi tentang bangun ruang kubus dan balok dengan menggunakan model pembelajaran kooperatif tipe NHT dengan alat peraga. langkah-langkah pembelajaran: (1) Siswa dibagi dalam kelompok dan setiap peserta didik dalam kelompok tersebut mendapat nomor kelompok; (2) Guru memberikan tugas yang berkaitan dengan materi pelajaran yang akan disampaikan dan masing-masing kelompok mengerjakannya bersama kelompoknya; (3) Setiap kelompok mendiskusikan jawaban yang benar dan memastikan tiap anggota kelompok dapat mengerjakannya atau mengetahui jawaban yang mewakili dari kelompok tersebut; (4) Untuk membahas hasil dari setiap kelompok tersebut, guru memanggil nomor kelompok tertentu untuk membahas jawaban mereka, kemudian memanggil nomor kelompok yang lain untuk memberi tanggapan atas jawaban dari kelompok yang mempresentasikan jawabannya; (5) Begitu seterusnya, hingga semua kelompok mendapatkan kesempatan untuk mempresentasikan hasil jawaban kelompok mereka dan kelompok yang lain menanggapinya dengan aktif dan interaktif; (6) Terakhir, guru memberikan kesimpulan terhadap jalannya pembahasan dan pembelajaran tersebut. Alat peraga dalam penelitian ini dibuat sendiri oleh peserta didik dengan tujuan agar peserta didik lebih memahami materi bangun ruang kubus dan balok.

Berdasarkan hasil analisis data diperoleh informasi bahwa terjadi peningkatan pemahaman lonsep dan kemampuan pemecahan masalah matematika peserta didik. Peningkatan tersebut antara lain dapat dilihat dari hasil tes akhir siklus I dan II. Di mana setiap butir soal yang digunakan pada setiap tes akhir siklus telah disesuaikan dengan indikator-indikator pemahaman konsep dan kemampuan pemecahan masalah. Pemecahan masalah matematika peserta didik terhadap indikator ini didapatkan dari hasil jawaban soal tes akhir siklus. Untuk lebih jelasnya, hasil penelitian telah diuraikan dan didapatkan data tentang pemahaman konsep dan kemampuan pemecahan masalah matematika peserta didik kelas VIII-C SMP Darul Ulum Muncar pada siklus I dan siklus II.

1) Pada tes akhir siklus I dari 30 peserta didik yang mengikuti tes akhir siklus diperoleh data banyak peserta didik yang tuntas adalah 20 peserta didik dan banyak peserta didik yang tidak tuntas belajar sebanyak 10 peserta didik dengan persentase $66,6 \%$.

2) Pada tas akhir siklus II dari 30 peserta didik yang mengikuti tes akhir siklus diperoleh data banyak peserta didik yang tuntas adalah 26 peserta didik dan banyak peserta didik yang tidak tuntas belajar sebanyak 4 peserta didik dengan persentase $86,6 \%$.

Berdasarkan hasil tes pemahaman konsep dan kemampuan pemecahan masalah matematika peserta didik pada materi bangun ruang kubus dan balok dalam penelitian ini, dapat diketahui bahwa pemahaman konsep dan kemampuan pemecahan masalah matematika peserta didik mengalami peningkatan sebesar 20\%. Persentase ketuntasan belajar tes hasil belajar matematika peserta didik pada materi bangun ruang kubus dan balok dapat dilihat pada tabel 7.

Tabel 7. Perbandingan Hasil Analisis Tes Akhir Siklus I dan II

\begin{tabular}{lllll}
\hline Siklus & Jumlah Peserta didik & Jumlah Peserta didik Tuntas & Persentase Keberhasilan & Keterangan \\
\hline I & 30 & 20 & $66,6 \%$ & Tidak Tuntas \\
II & 30 & 26 & $86,6 \%$ & Tuntas \\
\hline
\end{tabular}

Dari uraian di atas, dapat disimpulkan bahwa model pembelajaran kooperatif tipe NHT dengan alat peraga merupakan salah satu bentuk inovasi perbaikan kualitas pembelajaran matematika yang bertujuan untuk membantu peserta didik dalam meningkatkan pemahaman konsep dan kemampuan pemecahan masalah matematika peserta didik pada materi bangun ruang kubus dan balok. Sehingga dapat disimpulkan bahwa pada penelitian ini, penerapan model pembelajaran kooperatif tipe NHT dengan alat peraga dapat meningkatkan pemahaman konsep dan kemampuan pemecahan masalah matematika peserta didik materi bangun ruang kubus dan balok pada peserta didik kelas VIII-C SMP Darul Ulum Muncar tahun pelajaran $2017 / 2018$. 


\section{Penerapan Model Pembelajaran Kooperatif Tipe NHT}

Sebelum melaksanakan penelitian, terlebih dahulu peneliti menentukan lokasi penelitian yaitu SMP Darul Ulum. Kemudian pada hari Senin tanggal 16 April 2018 peneliti mendatangi SMP Darul Ulum dan menemui Kepala Sekolah yaitu Bapak Bachrudin, S.Pd untuk meminta izin mengadakan penelitian.

Pada hari yang sama Kepala sekolah mempertemukan peneliti dengan salah satu guru mata pelajaran matematika yaitu Bapak Syaikhul Hadi, S.Pd. Pada pertemuan ini peneliti mengadakan wawancara. Kemudian pada pertemuan selanjutnya peneliti mengadakan observasi dan meminta nilai Ujian Tengah Semester (UTS) Genap peserta didik.

Sesuai hasil wawancara peneliti dengan guru bidang studi matematika, observasi, dan UTS hal ini juga terjadi pada kelas VIII-C SMP Darul Ulum. Peserta didik pada kelas ini sebanyak 30, kesulitan dalam menguasai pemahaman konsep dan kemampuan pemecahan masalah matematika. Kesulitan tersebut terjadi karena pembelajaran matematika yang membosankan tanpa model dan media pembelajaran yang menarik. Guru hanya menggunakan buku paket dalam pembelajaran. Selain itu pembelajaran konvensional menjadi salah satu faktor kurangnya pemahaman konsep, kemampuan pemecahan masalah dan keaktifan peserta didik dalam kegiatan pembelajaran. Dalam hal ini akhirnya berdampak pada rendahnya pencapaian hasil belajar peserta didik. Berdasarkan kondisi tersebut, maka peneliti merencanakan pembelajaran matematika dengan menerapkan model pembelajaran kooperatif tipe NHT dengan alat peraga. Hal ini dilakukan peneliti untuk meningkatkan pemahaman konsep dan kemampuan pemecahan masalah matematika peserta didik kelas VIII-C SMP Darul Ulum tahun pelajaran 2017/2018. kooperatif tipe NHT merupakan suatu model pembelajaran berkelompok yang setiap anggota kelompoknya bertanggung jawab atas tugas kelompoknya, sehingga tidak ada pemisahan antara peserta didik yang satu dan peserta didik yang lain dalam satu kelompok untuk saling memberi dan menerima antara satu dengan yang lainnya (Shoimin, 2014:100). Menurut Slavin dalam (Huda, 2015:203) metode yang dikembangkan oleh Russ Frank ini cocok untuk memastikan akuntabilitas individu dalam diskusi kelompok. Alat peraga adalah media alat bantu pembelajaran, dan segala macam benda yang digunakan untuk memperagakan materi pembelajaran. Alat peraga mengandung pengertian bahwa segala sesuatu yang masih bersifat abstrak kemudian dikonkretkan dengan menggunakan alat peraga dapat dijangkau dengan pikiran yang sederhana dan dapat dilihat, dipandang, dan dirasakan (Arsyad, 2013:9).

Pelaksanaan pembelajaran dengan materi kubus dan balok dilaksanakan dalam dua siklus. Setiap siklus dilaksanakan dalam waktu tiga kali pertemuan. Pertemuan pertama dan kedua sebagai pemberian materi, sedangkan pertemuan ketiga dijadikan sebagai tes akhir siklus. Pada setiap pertemuan dalam pemberian materi waktu yang digunakan adalah 2 jam pelajaran, dimana setiap 1 jam pelajaran berlangsung selama 40 menit. Setiap pertemuan peneliti membagi menjadi beberapa tahapan, yaitu pendahuluan, kegiatan inti, dan penutup. Pada kegiatan pendahuluan pertama kali yang dilakukan peneliti adalah mengucapkan salam, berdoa dan memeriksa kehadiran peserta didik. Langkah selanjutnya peneliti menyampaikan indikator pembelajaran, materi yang akan dipelajari, dan menjelaskan rencana kegiatan pembelajaran yang akan dilaksanaksan menggunakan kooperatif tipe NHT dengan alat peraga. Kemudian peneliti memberikan apersepsi dan motivasi kepada peserta didik. Seorang peserta didik dapat belajar dengan giat karena motivasi dari luar, misalnya dorongan dari orang tua, janji-janji yang diberikan apabila ia berhasil atau sebagainya. Kegiatan ini berlangsung selama 10 menit.

Pada kegiatan inti berlangsung selama 60 menit. terdiri dari 5 fase yang akan diuraikan sebagai berikut.

(1) Fase 1: Penomoran

Peneliti membagi peserta didik menjadi 5 kelompok secara heterogen sesuai dengan yang telah direncanakan oleh peneliti yaitu didasarkan pada nilai Ujian Tengah Semester (UTS) Genap peserta didik, agar pembelajaran bisa optimal. Hal ini sejalan dengan pendapat Isjoni (2011:54) yang menyatakan bahwa "untuk mengoptimalkan manfaat belajar kelompok, keanggotaan kelompok sebaiknya heterogen". Kemudian peneliti membagikan nomor kepada setiap anggota kelompok dengan nomor yang berbeda-beda dalam satu kelompok. Kegiatan ini berlangsung selama 3 menit.

(2) Fase 2: Alat Peraga

Alat peraga adalah media alat bantu pembelajaran, dan segala macam benda yang digunakan untuk memperagakan materi pembelajaran.

(3) Fase 3: Pengajuan Pertanyaan

Peneliti pada tahap ini membagikan Lembar Kegiatan Peserta Didik (LKPD) yang harus diselesaikan. Pada LKPD tersebut terdiri dari beberapa pertanyaan yang mengarahkan peserta didik untuk memahami 
konsep dan memecahkan masalah dari kubus dan balok. Langkah selanjunya peneliti memancing peserta didik untuk bertanya tentang LKPD dan pembuatan alat peraga. Sejalan dengan pendapat Johan I Bolla (dalam Rusman, 2011:82) "proses pembelajaran setiap pertanyaan, baik berupa kalimat tanya atau suruhan yang menuntut respon peserta didik perlu dilakukan agar peserta didik memperoleh pengetahuan dan meningkatkan kemampuan berpikir". Kegiatan ini berlangsung selama 5 menit.

(4) Fase 4: Berpikir Bersama

Peneliti membimbing peserta didik untuk menyelesaikan pertanyaan dalam LKPD dengan alat peraga yang diberikan oleh peneliti. Selanjutnya peneliti juga membimbing peserta didik untuk mengaitkan materi, alat peraga, dengan nalar untuk menyelesaikan pertanyaan yang ada di LKPD. Sejalan dengan pendapat Rusman (2011:89) "keterampilan membimbing kelompok kecil adalah salah satu cara yang dapat dilakukan untuk memfasilitasi sistem pembelajaran yang dibutuhkan oleh peserta didik secara berkelompok". Kegiatan ini berlangsung selama 30 menit.

(5) Fase 5: Menjawab

Pada fase ini setelah diskusi selesai peneliti mengocok nomor dan memanggil satu nomor yang nomorya keluar waktu pengocokan, nomor yang terpanggil mengangkat tangannya dan keluar dari kelompok untuk melaporkan hasil diskusi mereka. Selanjutnya peneliti meminta peserta didik yang lain mendengarkan dan menanggapi jawaban dari kelompok yang presentasi, kemudian peneliti mengulang kegiatan mengocok nomor sampai semua pertanyaan terselesaikan. Kegiatan ini berlangsung selama 20 menit.

Pada kegiatan penutup ini yang dilakukan oleh peneliti adalah peneliti bersama peserta didik menyimpulkan hasil pembelajaran yang sudah dilakukan, peneliti menyampaikan tentang materi yang akan dipelajari pada pertemuan selanjutnya, kemudian peneliti berdoa bersama dan diakhiri dengan mengucapkan salam kepada peserta didik. Sejalan dengan pendapat Rusman (2011:92) "menutup (closure) pelajaran adalah kegiatan yang dilakukan pembelajaran. Kegiatan ini bermaksud untuk memberikan gambaran menyeluruh tentang apa yang telah dipelajari oleh peserta didik dan tingkat keberhasilan guru dalam proses pembelajaran". Kegiatan ini berlangsung selama 10 menit.

\section{Penerapan Model Pembelajaran Kooperatif Tipe NHT dengan Alat Peraga untuk Meningkatkan Pemahaman Konsep dan Pemecahan Masalah}

Penerapkan model pembelajaran kooperatif tipe kooperatif tipe NHT dengan alat peraga pada materi kubus dan balok dapat meningkatkan pemahaman konsep dan kemampuan pemecahan masalah matematika peserta didik. Hal ini dapat dilihat dari hasil tes akhir siklus II yang mengalami peningkatan dibandingkan tes akhir siklus I baik dalam rata-rata maupun persentase ketuntasan belajar peserta didik. Hal ini sejalan dengan pendapat Ibrahim, dkk. (dalam Isjoni, 2011:27) yang mengatakan bahwa "tujuan dari pembelajaran kooperatif adalah memperbaiki prestasi peserta didik atau tugas-tugas penting lainnya". Berdasarkan hasil penelitian yang telah dilaksanakan, didapatkan data tentang pemahaman konsep dan kemampuan pemecahan masalah matematika peserta didik kelas VIII-C SMP Darul Ulum yaitu.

1) Peserta didik dikatakan tuntas belajar, jika $\geq 75 \%$ peserta didik mendapatkan nilai pemahaman konsep dan kemampuan pemecahan masalah $\geq 75$. Pada siklus I dari 30 peserta didik diperoleh data yang tuntas belajar sebanyak 20 peserta didik dan data peserta didik yang tidak tuntas sebanyak 10 peserta didik dengan nilai rata-rata 70,46 sehingga persentase ketuntasan hanya 66,6\% pada siklus I. Pada tes siklus I ini belum mencapai kriteria yang ditentukan.

2) Pada siklus II dari 30 peserta didik diperoleh data yang tuntas belajar sebanyak 26 peserta didik dan peserta didik yang tidak tuntas sebanyak 4 peserta didik dengan nilai rata-rata 81,66 sehingga persentase ketuntasan $86,6 \%$. Pada tes siklus II ini sudah mencapai kriteria yang ditentukan.

Berikut merupakan data hasil penelitian yang didapat pada tindakan siklus I dan siklus II dalam model pembelajaran kooperatif tipe NHT dengan alat peraga.

Tabel 8. Data Hasil Penelitian Siklus I dan Siklus II

\begin{tabular}{lcccc}
\hline \multicolumn{1}{c}{ Kriteria Keberhasilan } & Siklus I & $\begin{array}{c}\text { Taraf Keberhasilan } \\
\text { Tindakan }\end{array}$ & $\begin{array}{c}\text { Siklus } \\
\text { II }\end{array}$ & $\begin{array}{c}\text { Taraf Keberhasilan } \\
\text { Tindakan }\end{array}$ \\
\hline $\begin{array}{l}\text { Nilai rata-rata kelas tes peserta didik } \geq \\
75\end{array}$ & 70,46 & Tidak Tuntas & 81,66 & Tuntas \\
$\geq 75 \%$ peserta didik mendapat nilai tes & $66,6 \%$ & Tidak Tuntas & $86,6 \%$ & Tuntas
\end{tabular}


$\geq 75$ terhadap guru

Persentase keberhasilan tindakan peserta didik

Peserta didik merasa senang dengan model pembelajaran kooperatif tipe NHT dengan alat peraga
$(20$

peserta

didik)

$72,09 \%$

Baik

$87,62 \%$

Sangat Baik

$69,73 \%$

Cukup Baik

$87,62 \%$

Sangat Baik

$50 \%$

(3 dari 6

Baik

$83,3 \%$

(1 dari 6

peserta

didik)

Berdasarkan Tabel 8, dapat disimpulkan bahwa penerapan model pembelajaran kooperatif tipe kooperatif tipe NHT dengan menggunakan alat peraga dapat meningkatkan pemahaman konsep dan kemampuan pemecahan masalah matematika peserta didik kelas VIII-C SMP Darul Ulum tahun pelajaran 2017/2018. Berdasarkan hasil penelitian dan pembahasan maka hipotesis yang berupa "penerapan model pembelajaran kooperatif tipe kooperatif tipe NHT dengan alat peraga dapat meningkatkan pemahaman konsep dan kemampuan pemecahan masalah matematika peserta didik kelas VIII-C SMP Darul Ulum materi bangun ruang kubus dan balok tahun pelajaran 2017/2018" dinyatakan dapat diterima

\section{SIMPULAN DAN SARAN}

Berdasarkan hasil penelitian dan serangkaian kegiatan tindakan pembelajaran dalam penelitian ini dapat disimpulkan bahwa penerapan model pembelajaran kooperatif tipe NHT dengan alat peraga dapat meningkatkan pemahaman konsep dan kemampuan pemecahan masalah matematika peserta didik materi bangun ruang kubus dan balok pada peserta didik kelas VIII-C SMP Darul Ulum Muncar tahun pelajaran 2017/2018. Berdasarkan paparan data dan pembahasan, peneliti menyarankan kepada berbagai pihak, sebagai berikut.

1) Bagi Sekolah

Bagi pihak sekolah, disarankan untuk memanfaatkan hasil penelitian ini agar termotivasi untuk lebih kreatif dalam memilih model pembelajaran dan penilaian berbasis kelas, sehingga dapat meningkatkan kualitas pembelajaran.

2) Bagi guru matematika

Model pembelajaran kooperatif tipe NHT dapat dijadikan sebagai salah satu alternatif pembelajaran yang dapat digunakan untuk meningkatkan pemahaman konsep dan kemampuan pemecahan masalah matematika peserta didik.

3) Bagi Peneliti selanjutnya

Bagi peneliti yang ingin mengembangkan dan menerapkan model pembelajaran kooperatif tipe NHT dengan alat peraga hendaknya menggunakan pokok bahasan lain dan harus cermat dalam mengatur waktu dalam proses pembelajaran. Karena jika tidak berhati-hati dalam mengatur pembelajaran dengan menggunakan model pembelajaran kooperatif tipe NHT dengan alat peraga tidak bisa berjalan dengan efektif. Adapun cara yang dapat digunakan untuk mensiasati kelancaran penerapan tersebut yaitu dengan memadukan model pembelajaran kooperatif tipe NHT dengan strategi atau model lainnya.

4) Bagi Siswa

Siswa dapat belajar lebih baik dan dapat memahami materi matematika secara mandiri. Siswa mendapatkan pengalaman baru tentang matematika menggunakan model pembelajaran kooperatif tipe NHT menggunakan alat peraga khususnya pada materi bangun ruang kubus dan balok.

\section{DAFTAR RUJUKAN}

Arsyad, A. (2013). Media Pembelajaran. Jakarta:Raja Grafindo Persada.

Huda, M. (2015). Cooperative Learning: Metode, Teknik, Struktur, dan Model Penerapan. Yogyakarta: Pustaka Pelajar.

Isjoni. (2011). Cooperative Learning. Bandung: Alfabeta.

Rusman. (2011). Model-Model Pembelajaran Mengembangkan Profesionalisme Guru. Jakarta: Rajawali Pers. 
Shoimin, A. (2014). 68 Model Pembelajaran INOVATIF dalam Kurikulum 2013. Yogyakarta: Ar-Ruzz Media.

Suherman \& Erman. (2001). Common Text Book Strategi Pembelajaran Kontemporer. Bandung: JICA-UPI. 